\title{
HISTORY AND MODERN STATUS OF THE BLACK-EARED WHEATEAR, OENANTHE HISPANICA (PASSERIFORMES, MUSCICAPIDAE), IN UKRAINE
}

\author{
A. N. Tsvelykh \\ Schmalhausen Institute of Zoology NAS of Ukraine, \\ vul. B. Khmelnytskogo, 15, Kyiv, 01030 Ukraine \\ E-mail:TSV@izan.kiev.ua
}

A. N. Tsvelykh (https://orcid.org/0000-0001-8970-5477)

\begin{abstract}
History and Modern Status of the Black-eared Wheatear, Oenanthe hispanica (Passeriformes, Muscicapidae), in Ukraine. Tsvelykh, A. N. - The history of research of the Black-eared Wheatear Oenanthe hispanica (L.) in Ukraine in XIX-XXI centuries is presented. The Black-eared Wheatear is now a rare breeding bird in the coastal area of the Crimean peninsula, and a very rare vagrant species on the other territory of Ukraine. Four breeding regions of the Black-eared Wheatear are found in the Crimean peninsula: seacoast between Sudak and Theodosia cities; neighbourhood of Sevastopol City; Tarkhankut peninsula; Kerch peninsula. The first two breeding regions have been known since the middle of XIX century. In the breeding regions, the breeding areas of the Black-eared Wheatear are not constant: the birds almost never nest in a place for a number of years. Oenanthe hispanica breeds in Crimea in the same biotopes as its sibling species, the Pied Wheatear, Oenanthe pleschanka, which is essentially more abundant there. The breeding of single Black-eared Wheatears with the numerous Pied Wheatears increases their interspecies hybridization, which is rather common on the Crimean peninsula. Three out of five individuals of Oenanthe hispanica collected in Crimea and stored in various museums turned out to be hybrids with Oenanthe pleschanka. The Black-eared and Pied Wheatears have hybridized in the Crimean peninsula for a long time: the hybrids have been recorded in XX and in XXI centuries. The hybrids do not occur in a specific breeding region, and can be found in any of those.
\end{abstract}

Key words: Oenanthe hispanica, history, distribution, hybridization, Ukraine, Crimea.

\section{Introduction}

Most of the Black-eared Wheatear's range is in the Mediterranean and the adjacent Western Asia regions, with an eastern border at the Transcaspian Region. In Ukraine, this species sporadically breeds in the coastal regions of the Crimean peninsula. On the other territory of Ukraine, it is a very rare vagrant species. The study is a review of the history of research, and the past and present state of the species in Ukraine. 
Material and methods

The results of bird surveys in the Crimean peninsula in 1993-2011 were used in present study. The published records of Oenanthe hispanica from the beginning of XIX century in Ukraine till now were analysed and critically considered. The birdwatcher reports of findings of the Black-eared Wheatear in the study area were also analysed. Of those, only the photographically-confirmed reports were used.

\section{Results and discussion}

The first findings of the Black-eared Wheatear on the study area have been reported in the first half of the XIX century. A. Nordmann (Nordmann, 1834) has briefly mentioned the distribution of Saxicola stapazina (one of the junior synonyms of Oenanthe hispanica, which had been frequently used in the XIX century) in Crimea. Later the author had added that Saxicola stapazina had been breeding in single pairs in the South Coast of Crimea (Nordmann, 1840). M. I. Kalenichenko (Kaleniczenko, 1839) had published the results of the zoological expeditions by Prof. I. Krinitsky to Crimea in 1836-1838. In the publication, he noted that Saxicola stapazina had occurred in Crimea in steppe near Yevpatoriya City. That finding was criticized by A. M. Nikolsky (1891) who suspected that Kalenichenko had used the name Saxicola stapazina for another species, the Northern Wheatear (Saxicola oenanthe, according to Nilolsky). Nikolsky has assumed that the Black-eared Wheatear had been recorded by Kalenichenko under the name Saxicola aurita (another synonym of Oenanthe hispanica that was in use in the XIX century). This is easily verified, because Kalenichenko included the detailed descriptions of birds in his species essays. According to those descriptions, Saxicola stapazina is indeed the Northern Wheatear, and Saxicola aurita is the Black-eared Wheatear in Kalenichenko's work. Thus, he gave the following reports on distribution and biotopes of Saxicola aurita in Crimea. The species had been found near Theodosia City "in desertis" (notation in Latin), and it had been sometimes seen by Krinitsky in "Beszterek", the location which Kalenichenko did not know (Kaleniczenko, 1839). Today, the toponym "Beszterek" is easily identified as Beshterek village, now Mazanka village in $15 \mathrm{~km}$ to the east by north-east of Simferopol City. Radde's report (Radde, 1854) about the finds of Saxicola stapazina near Simferopol City in Crimea and near Kakhovka town at the Dnipro River is based on a misunderstanding. All specimens of wheatears from Radde's collection, designated by him as S. stapazina, when checked by E. J. Homeyer (Homeyer, 1854) turned out to be the Pied Wheatear, Oenanthe pleschanka (Saxicola leucomela, according to Homeyer).

Near Sevastopol City, W. Carte (1858) collected Saxicola stapazina on May, 1855 and April, 1856. He emphasized that the species was significantly more rare in the region than the closely related Pied Wheatear (Saxicola leucomela, according to Carte), and he thought both species to be vagrant. T. Blakiston (1857), who conducted surveys in that region in 1855-1856 for twelve-month periods, found Saxicola stapazina among rocks and scrub brushwood in the middle of April. We assume that it was in April of 1856, considering the observations of birds he made in May of that year. Also two specimens of Oenanthe hispanica (males of the black- and white-throated morphs) were collected near Sevastopol city (Balaklava settlement) on May 1, 1908. Those birds were found in the collection of the Zoological institute, Russian Academy of Sciences (Loskot, 1976).

Also in the collection of the Zoological institute, Russian Academy of Sciences there is a black-throated male of Oenanthe hispanica, collected at Syuryu-Kaya on June 1, 1913 (Loskot, 1976; 1986). Syuryu-Kaya is a mountain range directly adjacent to the Karadag mountain range, which is in the southeastern coastal part of the Crimean Mountains (currently part of the Karadag nature reserve). Later, another Black-eared Wheatear was recorded in this part of Crimea. A white-throated male of this species was collected near Morskoye village in $15 \mathrm{~km}$ to the west by south-west of Sudak City, on the sea coast on May 31, 1973 (Kostin, 1983). The specimen is stored in the collection of National museum of Natural history National Academy of Sciences of Ukraine (Peklo, 2002). A pair of Black-eared Wheat- 


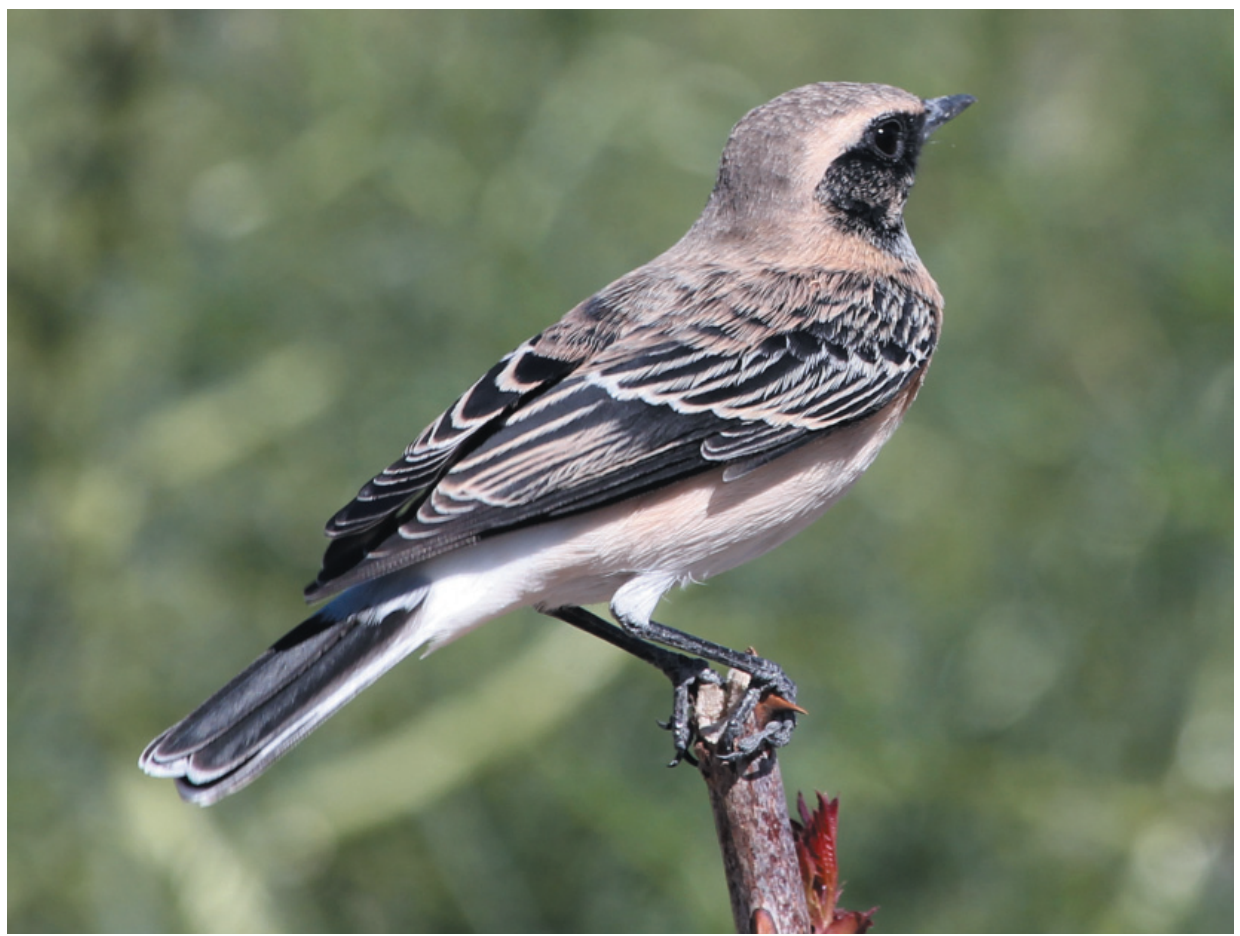

Fig. 1. Young male of the Oenanthe hispanica from Crimea, 28 August 2011. Photo by V. Khustochka.

ears was found in the breeding biotope on April, 17, 1986 (Beskaravainy, 2008). Two pairs of that species with nestlings of different ages were found at the sea coast of the Karadag bay and nearby at a steppe area with clay outcrops, on June 23 and 28, 1986, respectively (Kinda et al., 2003). Two Black-eared Wheatear males were recorded on a rocky seashore at Karadag on April 23, 1998 (one specimen was collected and is stored in the museum of the Karadag nature reserve). Later in May of that year, a Black-eared Wheatear female was observed near a nest in a gap in the masonry (Kinda et al., 2003). A pair of the Blackeared Wheatears was found on the steppe slope by the seacoast in the Lisya bay, nearby the Karadag bay, on June, 16, 1989. More to the west, a pair of birds was recorded on the western coast of cape Rybachy at the Meganom peninsula in 2002, and later on June, 25, 2003 (Kinda et al., 2003). Nearby, a Black-eared Wheatear was photographed in $3 \mathrm{~km}$ to the north on August, 28, 2011 (Khustochka, 2011). Judging by the photo, it was a young black-throated male that has not completed moult to the adult plumage (fig. 1). The same bird was probably recorded during the repeat survey on August, 31, 2011 (Khustochka, 2011). According to the given coordinates, $44^{\circ} 49^{\prime} 51.7^{\prime \prime} \mathrm{N}, 35^{\circ} 02^{\prime} 53.8^{\prime \prime} \mathrm{E}$, the bird was seen both times on a waste land at the southern edge of Kapsel village.

In the eastern Crimea, two pairs of Black-eared Wheatears with flying nestlings were recorded on the sea-facing slopes of Opuk Mountain, in the south-eastern part of the Kerch peninsula on June, 26, 1996 (Kostin, Beskaravainy, 1999). In the north-western part of the Kerch peninsula, seven birds of that species (adult and young) were observed near Rybnoye village on July, 3, 1998 (Kinda et al., 2003). Nearby, I found a bird near Kamenskoye village, which turned out to be a hybrid between Oenanthe hispanica and Oenanthe pleschanka on September, 22, 1992 (see below). A Black-eared Wheatear was also noted in the list of species observed on the Kerch peninsula during the survey of the overhead power lines in the steppe Crimea in 2012-2014 (Andryuschenko et al., 2014). It was later revealed that a bird (a black-throated female) was observed near Gornostayevka village in $25 \mathrm{~km}$ to the west by north-west from Kerch City, on October 6, 2013 (V. N. Kucherenko, personal communication). 


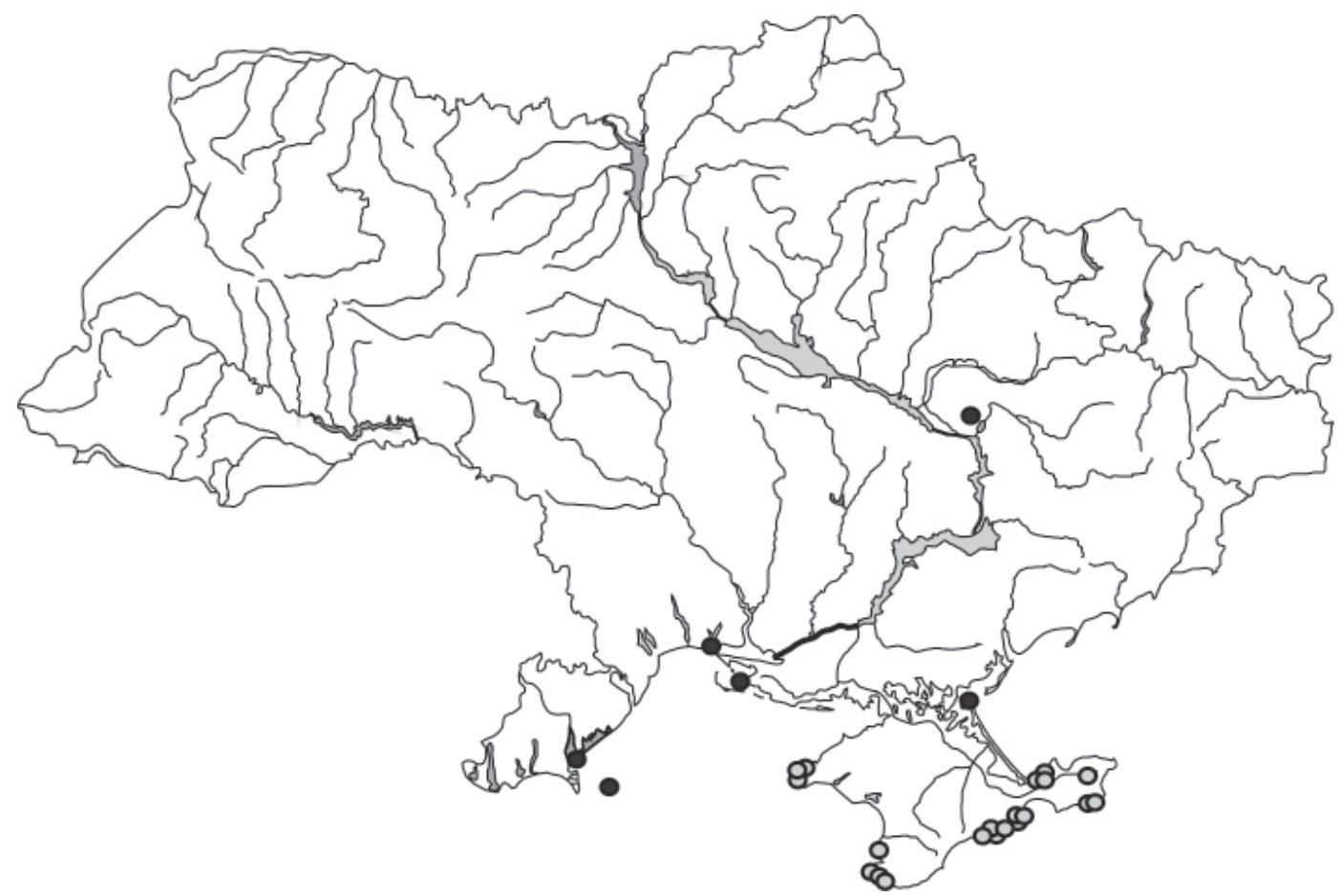

Fig. 2. Distribution of Oenanthe hispanica in Ukraine (according to data from 1984-2019): light circles are findings within the breeding area and black ones are findings of vagrant birds.

In the western Crimea, a Black-eared Wheatear male of the black-throated morph was recorded near Olenevka village at the western edge of the Tarkhankut peninsula on June 6, 2004 (Nastachenko, Bredbier, 2013). In the north part of the Tarkhankut peninsula, a male Black-eared Wheatear was seen on April 20, 2014. On June 16, 2015, another finding of a similar bird was reported at that location, pointing to the possibility of breeding (Kucherenko et al., 2017). On a western coast of Crimea, a song of Oenanthe hispanica was recorded on tape near the mouth of the Kacha River in $15 \mathrm{~km}$ from Sevastopol City, on June 7, 2017 (Lastukhin, 2017). To the south of Sevastopol City, a white-throated male of Black-eared Wheatear was found on a large flat top of a coastal cliff on the south-western coast of the Heraclea peninsula nearby cape Fiolent on May 17, 2002 (own data). During the two-hour observation, the bird made courtship displays in the air or fed on the ground. A female Black-eared Wheatear was frequently seen there, but no interaction between the birds was observed. This male was also recorded at that place in two weeks, on June 2, but the lengthy observations could not be conducted. At the same day, another male, a black-throated morph was found in $300 \mathrm{~m}$ to the east along the seashore at that location. Somewhat east of this place, near Balaklava, a black-throated male of Black-eared Wheatear was encountered on June 13, 2019 (Bazdyrev, 2013).

Findings of the Black-eared Wheatear are rare in Ukraine outside the Crimean peninsula (fig. 2). A black-throated male of that species was collected on Zmiinyi Island in the North-Western Pontic area region on April 30, 1984 (Korzyukov, 1985). That specimen is stored in the collection of the Zoological museum of the National museum of Natural history NAS of Ukraine (Peklo, 2002). The author (Korzyukov, 1985) also reported that previously he had observed the black-throated males of Black-eared Wheatear at Zmiinyi Island during the spring migrations, though he was not able to collect them. In the same region, a white-throated male of the Black-eared Wheatear was observed on the coastal dam of Lake Sasyk near the northern border of the Danube delta on April 7, 2017 (Yakovlev, 2018). In the North Pontic area the same bird was recorded in a forest belt near Ochakiv town on April 18, 2005 (Redinov, Petrovich, 2005) and a black-throated one was spotted 


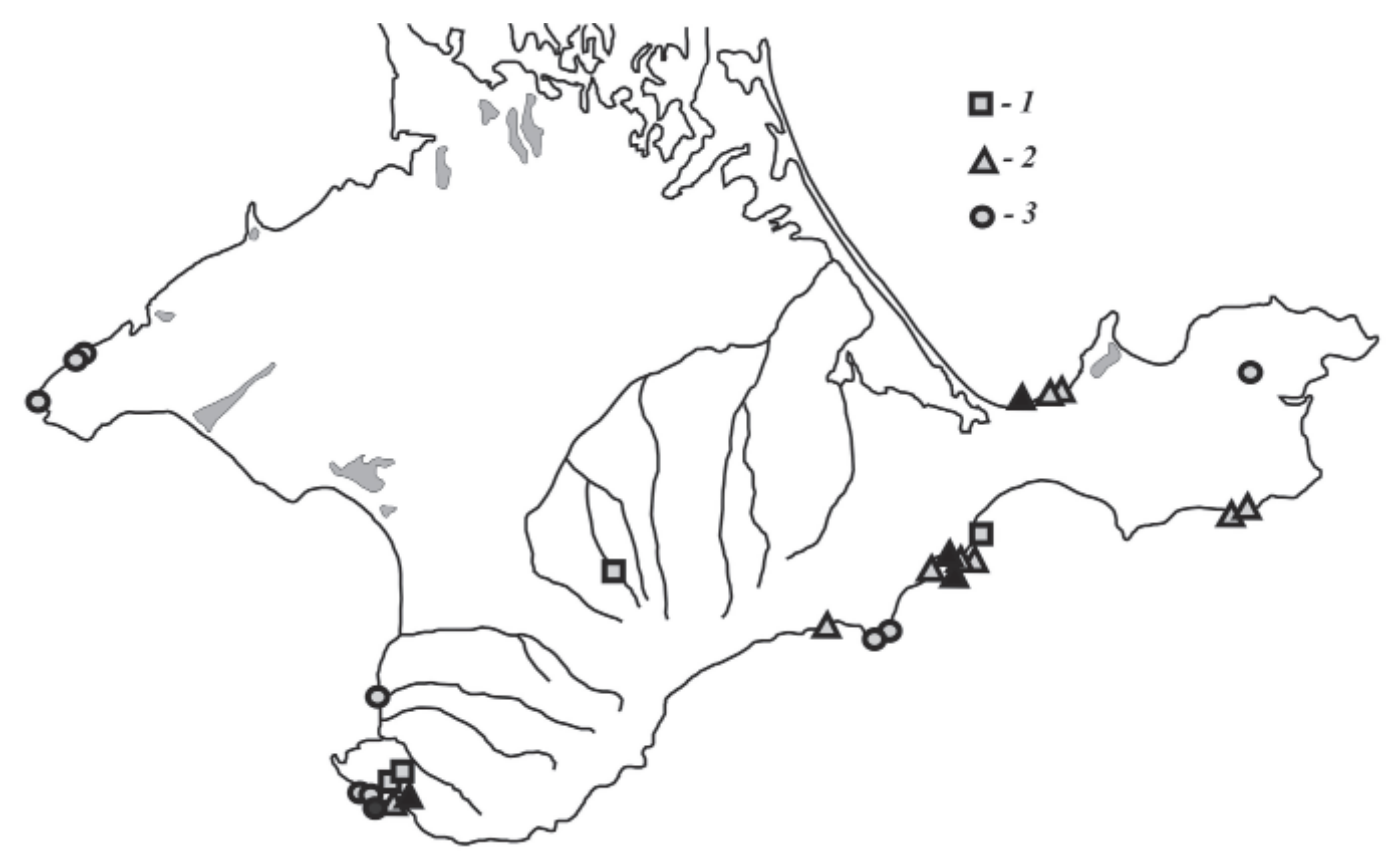

Fig. 3. Distribution of Oenanthe hispanica in Crimea in the 19th-21st centuries: 1 - 19th century, $2-$ 20th century, 3 - 21st century; black figures are findings of the Oenanthe hispanica and Oenanthe pleschanka hybrids.

on the Yagorlitskiy Kut peninsula in the Black Sea Biosphere Reserve on April 10, 2018 (Moskalenko, 2018). In the Northern Azov Sea region, another white-throated male was observed near the Genicheska Hirka village on May 11, 2019 (Fomina, 2019). In Ukraine, the most farther from the Crimean peninsula find of the Black-eared Wheatear was made in the Dnipropetrovsk Region. A white-throated male of that species was observed and photographed at the railroad tracks between the towns Pidhorodnye and Novomoskovsk, in $15 \mathrm{~km}$ to the north by north-east from Dnipro City, on May 1, 2013 (Nastachenko, Bredbier, 2013).

Four breeding regions can be established for the Black-eared Wheatear at the Crimean peninsula: the seacoast between the cities of Sudak and Feodosia, neighborhoods of Sevastopol City, the Tarkhankut peninsula and Kerch peninsula (fig. 2). Map of the Blackeared Wheatear findings (fig. 3), reported in different times, reveals that at least two of those breeding regions have existed on the Crimean peninsula for at least two centuries. However, the breeding areas of the species are not constant in the breeding regions. The birds almost never breed on the same place for many years consequently. This is confirmed by analyzing the frequency of Black-eared Wheatear nesting on the model areas, where the avifauna has been monitored for many years. Thus, the regular monitoring surveys were conducted in the Karadag Nature Reserve in 1975-2008 (Beskaravainy, 2008). During that time, the Black-eared Wheatear bred in the Karadag Nature Reserve only in 1986 and in 1998 (Kinda et al., 2003). The area of Opuk Mountain on the Kerch peninsula has also been surveyed frequently. There, the fauna of birds was studied thoroughly during the breeding seasons of 1943 (Frank, 1950), 1950 (Averin, 1951), 1951, 1961, 1970-1973, 1978, 1979, 1996-1999 (Kostin, Beskaravainy, 2002) and 2005 (own data). However, the breeding of the Black-eared Wheatear was recorded only in 1996 in that region (Kostin, Beskaravainy, 1999).

In Crimea, Oenanthe hispanica breeds in the same biotope as its sibling species Oenanthe pleschanka, which is significantly more abundant here. The density of Oenanthe pleschanka breeding was 2 pairs / $\mathrm{km}$ of sea shoreline at the south coast of the Heraclea 


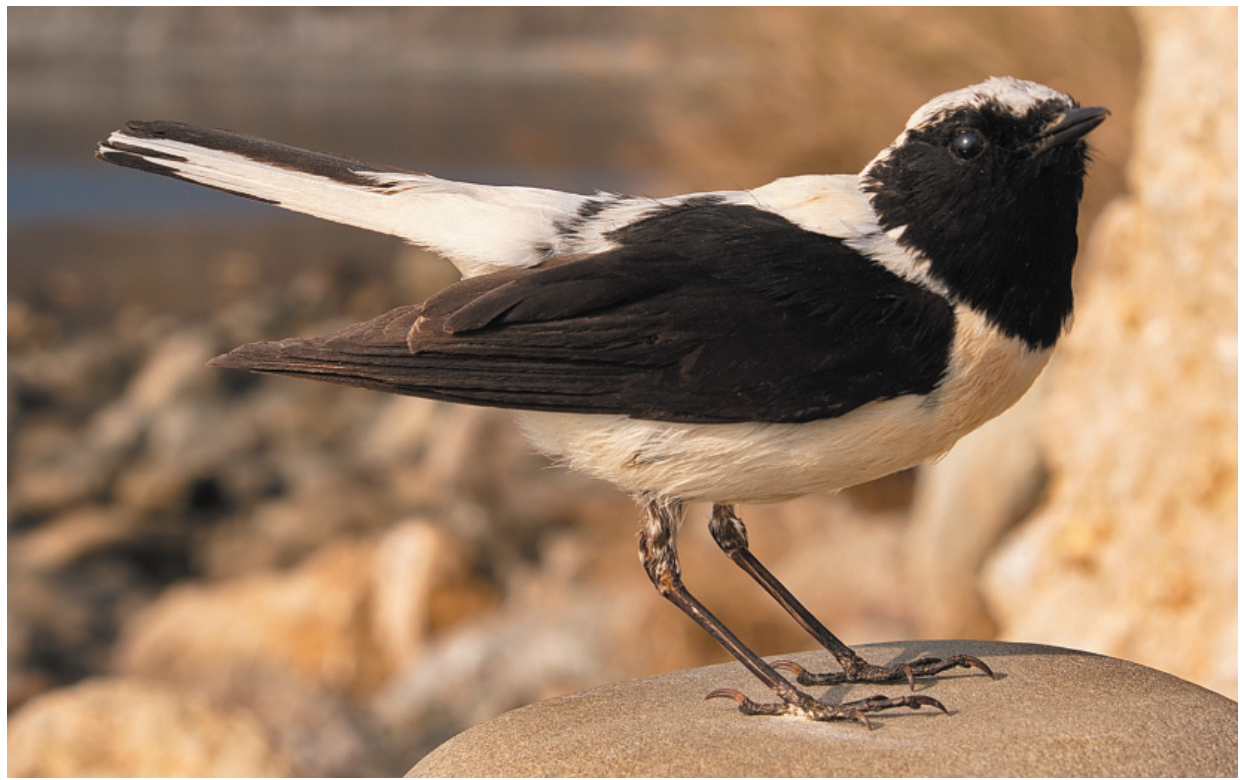

Fig. 4. A hybrid of the Oenanthe hispanica and Oenanthe pleschanka from Crimea, Karadag, April 23, 1998; Exposition of the museum of the Karadag nature reserve. Photo by M. Beskaravainy.

peninsula, 2.5 pairs / $\mathrm{km}$ in the coastal area of the Karadag Nature Reserve, 5.2 pairs / km at the coasts of the Meganom peninsula, 7.3 pairs / km at Opuk mountain (Beskaravainy, 2008) in the breeding biotopes of Oenanthe hispanica in the end of XX century and in early XXI century. The nests of Pied Wheatears are sometimes aggregated, in a shape of sparse colonies, in which the distance between the nests can be a few tens of meters (Kostin, 1983). The breeding areas of the Black-eared Wheatear are sometimes near those of the Pied Wheatear. Thus, at the south-western coast of the Heraclea peninsula, the distance between the nearest breeding areas of those species was no more than $100 \mathrm{~m}$ along the coastal cliff, at both sides (own data). It seems obvious that single pairs of the Black-eared Wheatear can

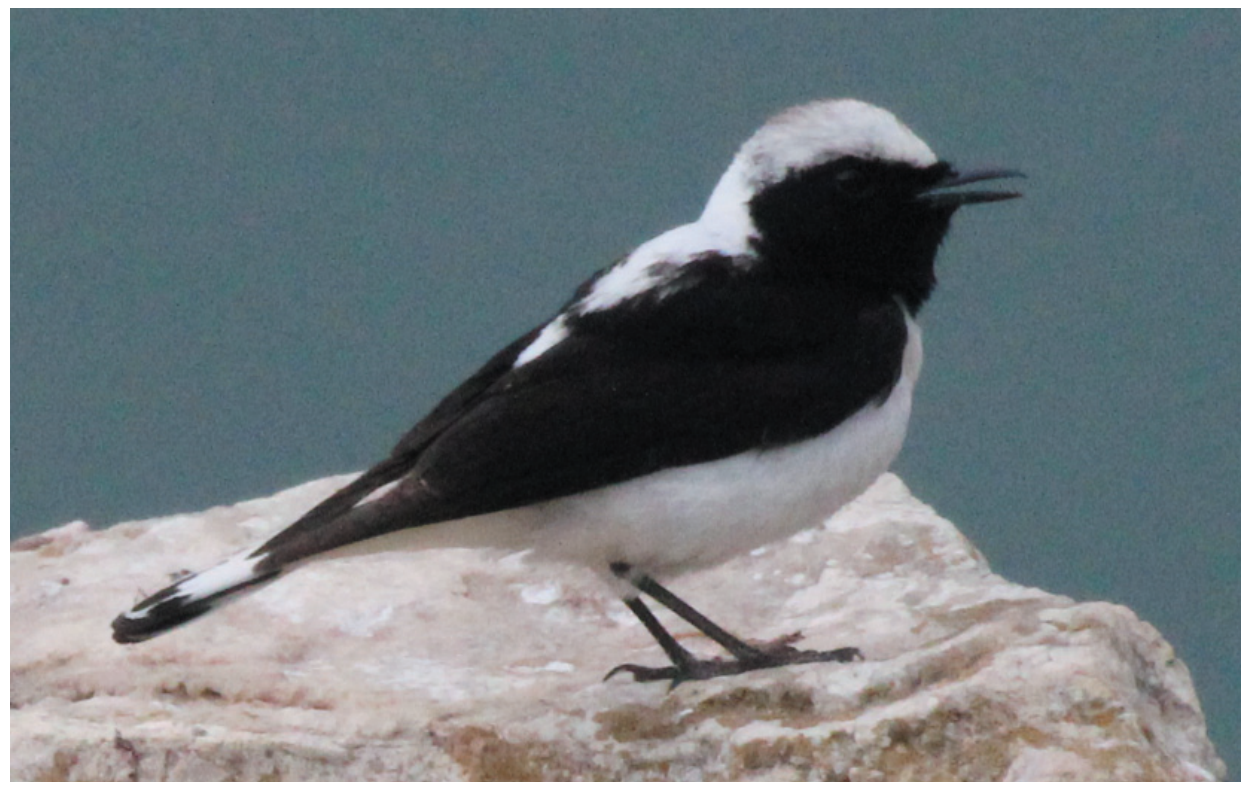

Fig. 5. A hybrid of the Oenanthe hispanica and Oenanthe pleschanka from Crimea, Balaklava, June 13, 2019. Photo by A. Bazdyrev. 
nest with the numerous Pied Wheatears, which enhances the chances of mixed pairs and hybridization of those species. Such hybrids have been found many times in Crimea.

The back of a Black-eared Wheatear male is white, and that of the Pied Wheatear male is black. The individuals with spotted back are found only in the areas of the secondary contact between the species, and are definitely hybrids (Loskot, 1986). Males with a narrow black stripe between the shoulders on a white back are also hybrids (Loskot, 1986). Two of the three Black-eared Wheatear males collected in Crimea at the beginning of XX century, were in truth hybrids (Loskot, 1986). One of them, caught in the vicinity of Balaklava on May 1, 1908 had a white back with isolated black feathers or spots on a white background. Another bird, caught in the eastern part of the peninsula on June 1, 1913, had a narrow black stripe on the white back between shoulders (Loskot, 1986). I saw a bird similar in color to the second one in the north-western part of the Kerch peninsula near Kamenskoye village on September 22, 1992. However, in the latter bird, a narrow transverse black stripe was located somewhat lower, at the lower edge of the back. The peculiarities of the coloration of a male Black-eared Wheatear caught on April 23, 1998 on the seashore near Karadag also testify to its hybrid origin (fig. 4). It had a distinctly pronounced narrow black band at the lower edge of the back, formed by black feathers, and, higher, rare black spots reaching the middle of the back. The same individual black spots were also present on the lateral surface of the bird's neck, which was white in the Black-eared Wheatear and black in the Pied Wheatear. The same color features are characteristic of the bird encountered near Balaklava on June 13, 2019 (fig. 5). It had a narrow black band and some black spots on the white back. The lateral surface of the bird's neck is black. Obviously, this bird is also a hybrid. In conclusion, it should be noted that all hybrids found in Crimea belonged to the black-throated morph.

Hence, the Black-eared Wheatear and the Pied Wheatear hybridization on the Crimean peninsula has been occurred for a long time. Interestingly, three of five specimens of the Black-eared Wheatear collected in Crimea and stored in collections of different museums are really hybrids between Oenanthe hispanica and Oenanthe pleschanka. That may indicate that on the Crimean Peninsula, hybridization between these species occurs quite often. The appearance of hybrids is not confined to any breeding area and they can be found in any of them (fig. 3).

I am very grateful to A. Bazdyrev, M. Beskaravainy and V. Khustochka for the very valuable photographs provided for this study.

\section{References}

Andryushchenko, Yu. O., Kucherenko, V. M., Popenko, V. M. 2014. Monitoring results of deaths of wild birds from contacts with overhead power lines in the Crimea in 2012-2014. Branta, 17, 104-132 [In Russian].

Averin, Yu. V. 1951. Birds of the Opuk mountains as a source population of protective forest plantations of the Kerch Peninsula. Transactions of the Crimean branch of Academy of Sciences, USSR. Zoology, 2, 11-19 [In Russian].

Bazdyrev, A. 2013. Oenanthe hispanica. https://uabirds.org

Beskaravainy, M. M. 2008. Birds of seacoasts of Southern Crimea. Nizhnia Orianda, Simferopol, 1-160 [In Russian].

Blakiston, T. 1857. Birds of the Crimea. Zoologist, 4, 5502-5515.

Carte, W. 1858. Observations during the Campaign of 1854, 1855, and 1856, on the Crimea, its Climate and Zoology. The Journal of the Royal Dublin Society, 1, 250-280.

Fomina, O. 2019. Oenanthe hispanica. https://uabirds.org

Frank, F. 1950. Die Vogel von Opuk (Schwarzmeer-Gebiet). Bonner zoologische Beiträge, 1 (2-4), 144-214 [In German].

Homeyer, E. J. 1854. Bemerkungen zu Hrn. Radde's Beitragen zur Ornithologie Sud-Russlands. Journal für Ornithologie, 4 (10), 363-366 [In German].

Kaleniczenko, M. J. 1839. Series animalium, a defuncto professore Joan. Krynicki, in itinereannis 1836-1838, ad Caucasum et Tauridem suscepto collectorum et nunc museo zoologico Caesareae universitatis Charcoviensis adscriptorum. Bulletin de la Société Impériale des naturalistes de Moscou, 2, 203-297 [In Latin].

Khustochka, V. 2011. Checklist S20433693, S20433696. https://ebird.org. 
Kinda, V. V., Beskaravainy, M. M., Diadicheva, E. A., Kostin, S. Yu., Popenko, V. M. 2003. Revision of rare, poor known and vagrant species of Passerines (Passeriformes) in the Crimea. Branta, 6, 25-58 [In Russian].

Korzyukov, A. I. 1985. Finds of the Black-eared Wheatear and the Great Spotted Cuckoo in the north-western Black Sea region. Vestnik Zoologii, 5, 84-85 [In Russian].

Kostin, Yu. V. 1983. Birds of the Crimea. Nauka, Moscow, 1-241 [In Russian].

Kostin, S. Yu., Beskaravainy, M. M. 1999. New data on the Birds of the Crimea. In: Fauna, ecology and conservation of Birds in the Azov-Black Sea region. SONAT, Simferopol, 23-26 [In Russian].

Kostin, S. Yu., Beskaravainy, M. M. 2002. Fauna and distribution of birds in the Opuk Nature Reserve (the Crimea). Nature reserves in Ukraine, 8 (1), 62-69 [In Russian].

Kucherenko, V. M., Prokopenko, S. P., Zherebtsova, T. A., Zherebtsov, D. Yu. 2017. Observations of rare bird species in the Crimea in 2013-2017. Berkut, 26 (1), 1-4 [In Ukrainian].

Lastukhin, A. 2017. XC375026, XC375027, XC375028. www.xeno-canto.org.

Loskot, V. M. 1976. On the systematic position of the Black-eared Wheatear and Pied Wheatear [Oenanthe hispanica (L.) and Oenanthe pleschanka (Lepech.)]. Proceedings of the Zoological Museum of the Institute of Zoology of the AN Ukrainian SSR, 36, 84-89 [In Russian].

Loskot, V. M. 1986. Phenotypic composition of populations in the zones of secondary contact between the Black-eared Wheatear and Pied Wheatear. In: Actual problems of Ornithology. Nauka, Moscow, 17-33 [In Russian].

Moskalenko, Yu. 2018. Oenanthe hispanica. https://uabirds.org

Nastachenko, A. S., Bradbier, P. 2013. New bird species of Dnipropetrovsk region. Berkut, 22 (1), 75-80\&83 [In Russian].

Nikolsky, A. M. 1891. Vertebrates of Crimea. Proceedings of the Imperial Academy of Sciences. Appendix to Volume 68, 4 (1), 1-484 [In Russian].

Nordmann, A. 1834. Catalogus Avium in Rossia meridionali observatarum. Bulletin de la Société Impériale des naturalistes de Moscou, 7, 445-451 [In Latin].

Nordmann, A. 1840. Observations sur la Fauna Pontique. In: Voyage dans la Russie meridionale et la Crimee, par la Hongrie, la Valachie et la Moldavie excute en 1837, sous la direction de M. Anatole de Demidoff. 3. Paris, 73-108 [In French].

Peklo, A. M. 2002. Catalogue of collections of the Zoological Museum, NSNHM, NAS of Ukraine. Birds. Vol. 3. Passeriformes. Zoological Museum NSNHM NAS of Ukraine, Kiev, 1-312 [In Russian].

Radde, G. 1854. Beitrage zur Ornithologie Sud-Russlands nach Beobachtungen i. J. 1852-53. Journal für Ornithologie, 1 (7), 52-64 [In German].

Redinov, K. O., Petrovich, Z. O. 2005. Record of Black-eared Wheatear in Mykolayiv region. Berkut, 14 (2), 188 [In Ukrainian].

Yakovlev, M. V. 2018. Interesting Faunal Sightings in the Danube region of Ukraine for the period 2015-2018. In: Major Aspects of Bird Studies and Conservation. Proceedings of the XXXVII International Scientific Conference of the Azov-Black Sea Ornithological Working Group, Tatarbunary, 207-215 [In Ukrainian].

Received 25 November 2020

Accepted 5 January 2021 